\title{
Primary open angle glaucoma and hypothyroidism
}

This article was published in the following Dove Press journal:

Clinical Optometry

13 January 2010

Number of times this article has been viewed

\section{George Kitsos' \\ Chrisavgi Pappa' \\ Agathoklis Tsatsoulis ${ }^{2}$ \\ 'Department of Ophthalmology, Department of Internal Medicine, Medical School, University of loannina, loannina, Greece; ${ }^{2}$ Endocrinology Clinic, Department of Internal Medicine, Medical School, University of loannina, loannina, Greece}

Correspondence: George Kitsos

Department of Ophthalmology, University of loannina, School of Medicine, 45 I I0,

loannina, Greece

$\mathrm{Tel}+302651042504$

Fax +302651049709

Email gkitsos@cc.uoi.gr
Purpose: To test the hypothesis: is there an association between primary open angle glaucoma (POAG) and hypothyroidism, and to establish the necessity of routine examination of thyroid function in these patients?

Design: Observational cross sectional study.

Materials and methods: 78 consecutive patients with a previous diagnosis of POAG and 77 control patients were evaluated for hypothyroidism. The levels of thyroid-stimulating hormone, free thyroxin and triiodothyronine were measured.

Results: No patient had hypothyroidism and no correlation was found between glaucoma and either thyroid-stimulating hormone, free thyroxin or triiodothyronine.

Conclusion: This study determined there is no an association between glaucoma and hypothyroidism. Therefore, we believe that the systematic screening for hypothyroidism in all patients with POAG is unnecessary.

Keywords: primary open angle glaucoma, hypothyroidism, intraocular pressure, thyroid hormones

\section{Introduction}

The literature contains contradictory studies regarding the existence of an association between hypothyroidism and primary open angle glaucoma (POAG). ${ }^{1-7}$ Cheng and Perkins $^{1}$ reported that among patients with hypothyroidism only $2 \%$ had glaucoma. Becker and colleagues ${ }^{2}$ studied the possible presence of myxedema of the trabecular meshwork in patients with abnormal thyroid function. Smith and colleagues ${ }^{3}$ found that $23.4 \%$ of the patients with POAG had hypothyroidism. Safran ${ }^{4}$ then hypothesized that there is a category of patients, who are predisposed to increased intraocular pressure (IOP) in hypothyroidism. However, Muñoz-Negrete and colleagues ${ }^{5}$ reported that only $2.67 \%$ among patients with POAG had hypothyroidism and Karadimas and colleagues $^{6}$ in 2001 found there was no association between POAG and hypothyroidism and also no correlation between intraocular pressure before and after treatment of hypothyroidism.

However, several studies have proposed that the systematic screening for hypothyroidism should be undertaken in all patients with POAG; a costly practice. Therefore, a clinical study was designed to determine if a relationship exists between POAG and hypothyroidism.

\section{Materials and methods}

A prospective study was organized in a case control fashion. A patient pool of 155 subjects were studied. The case group consisted of 78 consecutive patients with 
POAG, presenting to the Glaucoma Unit of the University Hospital of Ioannina, Greece. The control group included 77 age and sex-matched healthy subjects presenting to the General Unit of the Ophthalmology Department. Patients younger than 40 years of age were excluded in both groups.

Diagnostic criteria for POAG at the time of diagnosis and for the purposes of this study were intraocular pressure $>21 \mathrm{mmHg}$, measured by applanation tonometry, glaucomatous visual field defects and glaucomatous optic nerve damage. Visual fields were examined by automated perimetry (Humphrey 30-2 program; Humphrey-Zeiss, San Leandro, CA). Glaucomatous visual field defects were considered as; the presence of 2 or more adjacent points of $>5 \mathrm{~dB}$ loss each, (as compared with the age-adjusted normal values), the presence of a single point of $>10 \mathrm{~dB}$ loss, a difference of $>5 \mathrm{~dB}$ across the nasal horizontal meridian at two or more adjacent points, or a Glaucoma Hemifield Test outside of the normal limits $(P<0.01)$. Reproducibility of defects was checked by a second visual field and, in case of discrepancy, by a third. Examination of the optic disks was performed after pupil dilatation. The findings were photographically documented and reviewed by an independent reader. Signs of glaucomatous optic nerve damage were considered: the presence of local notching or thinning of the neuroretinal rim, or the presence of nerve fiber loss. ${ }^{8}$

The angle of the anterior chamber was open. Patients with pseudoexfoliation, pigment dispersion and other secondary open angle glaucomas were excluded.

During this study, within the POAG group, all patients received medical treatment for glaucoma and their intraocular pressures were $<21 \mathrm{mmHg}$.

The diagnosis of hypothyroidism was based on the measurements of thyroid-stimulating hormone (TSH) obtained by immunoradiometric assay (ventrex-coated tube radioimmunoassay, high sensitivity TSH) and free thyroxin $\left(\mathrm{FT}_{4}\right)$. The patients were also asked for their history of thyroid disease or thyroxin replacement therapy.

The diagnosis of hypothyroidism was based on TSH values being $>4.94 \mu \mathrm{IU} / \mathrm{mL}, \mathrm{FT}_{4}$ values $<0.70 \mathrm{ng} / \mathrm{dL}$ and clinical symptoms of hypothyroidism. Symptoms of hypothyroidism included; fatigue; apathy; arthralgias; generalized slowing speech, cold intolerance, coarse dry skin, hoarse voice, constipation, headaches and weight gain. Myxedema develops secondary to the accumulation of hydrophilic mucopolysaccharides in the ground substance of the dermis, as well as other tissues, leading to thickening of the facial features and doughy induration of the skin. ${ }^{9,10}$ Ocular findings in hypothyroidism include ciliary alopecia, ptosis, strabismus, cataract, and nyctalopia. ${ }^{11}$

Hypothyroidism was classified as subclinical, when TSH values were $>4.94 \mu \mathrm{IU} / \mathrm{mL}$, in the presence of normal serum free thyroxin $\left(\mathrm{FT}_{4}\right)$ (normal range $0.70-1.48 \mathrm{ng} / \mathrm{dL}$ ). ${ }^{9,10}$

Results are given as mean \pm standard deviation (SD) followed by the range of minimum-maximum values. An independent t-test and $\chi^{2}$ test were used for comparison between groups. The level of statistical significance was set at $P<0.05$.

\section{Results}

The study included 78 patients with POAG, 40 females $(51.3 \%)$ and 38 males $(48.7 \%)$ with the mean age of $68.0 \pm 7.35$ years. The control group included 77 patients, 39 females $(50.7 \%)$ and 38 males $(49.3 \%)$ with a mean age of $67.28 \pm 10.05$ years. None of the subjects in either group reported previous thyroxin replacement therapy. The mean age and sex distribution was not significantly different in the control group $(P=0.59)$ (see Table 1). An independent t-test was used for comparison between the two groups.

Hormonal determinations were performed in both groups. The mean value of TSH was $1.19 \pm 0.62 \mu \mathrm{IU} / \mathrm{mL}$ (range $0.03-3.6$ ) and $1.07 \pm 0.94 \mu \mathrm{IU} / \mathrm{mL}$ (range 0.03-7.33) in both the POAG and control groups respectively. The differences between groups were not statistically significant $(P=0.29)$ (see Table 1).

The mean value of $\mathrm{FT}_{4}$ was $1.22 \pm 0.25 \mathrm{ng} / \mathrm{dL}$ (range $0.79-1.95$ ) and $1.22 \pm 0.29 \mathrm{ng} / \mathrm{dL}$ (range 0.75-1.79) in both the POAG and control groups respectively. The differences between the groups were also not statistically significant $(P=0.89)$ (see Table 1).

The mean value of $\mathrm{T}_{3}$ was $1.039 \pm 0.20 \mathrm{ng} / \mathrm{mL}$ (range $0.735-1.338$ ) and $1.025-0.18 \mathrm{ng} / \mathrm{mL}$ (range 0.711-1.327) in both the POAG and control groups respectively. The differences were again not statistically significant $(P=0.90)$ (see Table 1).

No glaucoma patient had TSH values $>4.94 \mu \mathrm{IU} / \mathrm{mL}$ and only 5 patients had TSH values $<0.35$. We did not found any significant differences between the control and POAG groups. Two patients had $\mathrm{FT}_{4}>1.48 \mathrm{ng} / \mathrm{dL}$, one in the glaucoma and one in the control group. These differences were not statistically significant between the 2 groups (Table 1).

Moreover, no glaucoma patient and no subject of control group had $\mathrm{FT}_{4}$ values $<0.70 \mathrm{ng} / \mathrm{dL}$ and $\mathrm{T}_{3}$ values $<0.50 \mathrm{ng} / \mathrm{mL}$ (Table 1). 
Table I Demographic characteristics and laboratory findings

\begin{tabular}{|c|c|c|c|}
\hline & POAG group & Control group & $P$ value \\
\hline Number of subjects & 78 & 77 & \\
\hline Age (years), mean (SD) & $68(7.35)$ & $67.27(10.05)$ & 0.59 (NS) \\
\hline \multicolumn{4}{|l|}{ Sex } \\
\hline Females, n (\%) & $40(5 \mid .3)$ & $39(50.7)$ & \\
\hline Males, n (\%) & $38(48.7)$ & $38(49.3)$ & \\
\hline \multicolumn{4}{|l|}{ Previous therapy with thyroxin } \\
\hline $\mathrm{TSH}(\mu \mathrm{IU} / \mathrm{mL})$, mean $(\mathrm{SD})$ & $1.192(0.62)$ & I.07। (0.94) & 0.29 (NS) \\
\hline Patients with TSH $>4.94 \mu \mathrm{lU} / \mathrm{mL}, \mathrm{n}(\%)$ & $0(0)$ & $\mathrm{I}(\mathrm{I} .3)$ & $0.30(N S)$ \\
\hline Patients with TSH $<0.35 \mu \mathrm{lU} / \mathrm{mL}, \mathrm{n}(\%)$ & $5(6.4)$ & $4(5.2)$ & 0.70 (NS) \\
\hline $\mathrm{FT}_{4}(\mathrm{ng} / \mathrm{dL})$, mean $(\mathrm{SD})$ & $1.217(0.25)$ & $1.22(0.29)$ & 0.89 (NS) \\
\hline Patients with $\mathrm{FT}_{4}<0.70 \mathrm{ng} / \mathrm{dL}, \mathrm{n}(\%)$ & $0(0)$ & $0(0)$ & $\mathrm{I} .00$ (NS) \\
\hline Patients with $\mathrm{FT}_{4}>1.48$ ng/dL, n (\%) & $2(2.56)$ & $2(2.6)$ & 0.98 (NS) \\
\hline $\mathrm{T}_{3}(\mathrm{ng} / \mathrm{mL})$, mean $(\mathrm{SD})$ & $1.029(0.20)$ & $1.025(0.18)$ & 0.90 (NS) \\
\hline Patients with $\mathrm{T}_{3}<0.50 \mathrm{mg} / \mathrm{mL}, \mathrm{n}(\%)$ & $0(0)$ & $0(0)$ & $\mathrm{I} .00$ (NS) \\
\hline Patients with subclinical hypothyroidism, n (\%) & $0(0)$ & $\mathrm{I}(\mathrm{I} .3)$ & 0.30 (NS) \\
\hline Patients with clinical hypothyroidism, n (\%) & $0(0)$ & $0(0)$ & $\mathrm{I} .00$ (NS) \\
\hline
\end{tabular}

Abbreviations: POAG, primary open angle glaucoma; NS, not statistically significant; $\mathrm{TSH}$, thyroid stimulating hormone; $\mathrm{FT}_{4}$, free thyroxine; $\mathrm{T}_{3}$, triiodothyronine.

Only one case of subclinical hypothyroidism was detected in the control group and none in the POAG group (Table 1).

In our study, we did not investigate any possible correlation between the IOP of the two groups with TSH, $\mathrm{FT}_{4}$ and $\mathrm{T}_{3}$ values because in the POAG group all patients, during this study, received medical treatment of glaucoma and their intraocular pressure were $<21 \mathrm{mmHg}$.

\section{Discussion}

Hypothyroidism can be a difficult diagnosis to make because the classic symptoms can often be found in the normal elderly population. $^{12,13}$

Bilous and Tunbridge ${ }^{14}$ in the epidemiology of hypothyroidism stated that hypothyroidism can be found in 5\% of the population, $1 \%$ as previously diagnosed and $4 \%$ newly diagnosed, with elevated TSH. In 1920 Hertel $^{15}$ reported an elevation of IOP after induced hypothyroidism in rabbits although other experimental studies failed to demonstrate these results. ${ }^{16}$ Later McLenachan and Davies ${ }^{17}$ in 1965 reviewed the illnesses of 100 patients with open angle glaucoma and assessed them for hypothyroidism on a clinical and biochemical basis. Thyroid abnormalities were found in 45 patients, 16 of these were said to be myxedematous. However, the analytical procedures and the diagnostic criteria of hypothyroidism and POAG used in this study were inaccurate. For this reason their study was appropriately criticized by Cheng and Perkins ${ }^{1}$ in 1967 and the thyroid tests used in that study are now considered outdated and inaccurate when compared with modern evaluation quantifying TSH. An added criticism is that $38 \%$ of POAG patients were deemed open-angle glaucoma with elevated intraocular pressure alone. Consequently Cheng and colleagues found no association between hypothyroidism and POAG, added to this the small size of the sample (13 patients) and the fact that hypothyroid patients already received replacement therapy precludes reliable conclusions. Kruppin and colleagues ${ }^{18}$ in 1977 also concluded that POAG was not associated with an increased prevalence of low thyroid function. Then a study by Smith and colleagues ${ }^{3}$ in 1993 is often used to suggest that a strong relationship exists between hypothyroidism and POAG. The authors reported that hypothyroidism was present in $23.4 \%$ of patients affected with POAG. They proposed that in the hypothyroid state, hyaluronic acid accumulates in the trabecular meshwork and/or aqueous humor, causing an obstruction to intraocular drainage and that this accumulation would reverse with treatment of the hypothyroidism. Gentanni and colleagues ${ }^{19}$ found that IOP is increased even in subclinical hypothyroid patients and that, at this early stage, the impairment is fully reversible with $\mathrm{L}-\mathrm{T}_{4}$ therapy. However, the diagnosis of POAG was based mainly on intraocular pressure and was not confirmed by optic disc or visual field evaluations. This fact could explain why Gentanni did not find any patients with POAG among subthyroid patients 
despite a greater IOP ( $3 \mathrm{mmHg}$ ) present in these patients. Girkin and colleagues ${ }^{20}$ in 2004 demonstrated that there was a significantly greater risk of subjects with a pre-existing diagnosis of hypothyroidism developing glaucoma, compared with normal controls in a large male population from the Veterans Affairs Medical Center in Birmingham, Alabama. Three recent studies of Muñoz-Negrete ${ }^{5}$ in 2000, Karadimas ${ }^{6}$ in 2001 and Motsko ${ }^{21}$ in 2008, demonstrated no association between hypothyroidism and POAG. The diagnostic criteria of these entities are similar to the criteria used in the present study.

In our study we investigated the presence of clinical and subclinical hypothyroidism among patients with POAG, opting for strict definitions of hypothyroidism and glaucoma. None of the subjects in both groups (POAG and control group) had $\mathrm{TSH}$ values greater than $4.94 \mu \mathrm{IU} / \mathrm{mL}$ and $\mathrm{FT}_{4}$ values lower than $0.70 \mathrm{ng} / \mathrm{dL}$. Only one case of subclinical hypothyroidism was detected among healthy subjects; rates that are similar to those of the general population.

In conclusion, we have not been able to demonstrate the previously reported relationship between hypothyroidism and POAG. Therefore, despite the fact that several studies have reported contradictory results, leading to confusion as to whether the examination of thyroid function should be routine in all patients newly diagnosed with glaucoma; a rather expensive strategy. From the results of our study we cannot recommend the systematic screening in patients affected with POAG for thyroid dysfuction.

\section{References}

1. Cheng H, Perkins ES. Thyroid disease and glaucoma. Br J Ophthalmol. 1967;51(8):547-553.

2. Becker B, Kolker AE, Ballin N. Thyroid function and glaucoma. Am J Ophthalmol. 1966;61(5 Pt 2):997-999.

3. Smith KD, Arthurs BP, Saheb N. An association between hypothyroidism and primary open-angle glaucoma. Ophthalmology. 1993;100(10):1580-1584.

4. Safran AB. Are only certain hypothyroid subjects predisposed to raised intraocular pressure? Eur J Endocrinol. 1997;136(6):581-582.

Clinical Optometry

\section{Publish your work in this journal}

Clinical Optometry is an international, peer-reviewed, open access journal publishing original research, basic science, clinical and epidemiological studies, reviews and evaluations on clinical optometry. All aspects of patient care are addressed within the journal as well as the practice of optometry including economic and business analyses. Basic and clinical

Submit your manuscript here: http://www.dovepress.com/clinical-optometry-journal
5. Muñoz-Negrete FJ, Rebolleda G, Almodóvar F, Díaz B, Varela C. Hypothyroidism and primary open-angle glaucoma. Ophthalmologica. 2000;214(5):347-349.

6. Karadimas P, Bouzas EA, Topouzis F, Koutras DA, Mastorakos G. Hypothyroidism and glaucoma. A study of 100 hypothyroid patients. Am J Ophthalmol. 2001;131(1):126-128.

7. Pache M. Primary open-angle glaucoma and systemic diseases. Ophthalmologe. 2007;104(5):431-441; quiz 442-443. German.

8. American Academy of Ophthalmology. Primary open-angle glaucoma. In: Glaucoma: American Academy of Ophthalmology. San Francisco, 2008-2009:85-96.

9. Jameson JL, Weetmann AP. Disorders of thyroid gland. Harrison's Principles of Internal Medicine: Fauci AS, Braunwald E, et al. (17th ed). New York: McGraw-Hill Professional, 2008:2224-2246.

10. Billewicz WZ, Chapman RS, Crooks J, et al. Statistical methods applied to the diagnosis of hypothyroidism. Q J Med. 1969;38(150):255-266.

11. Ducasse A, Schlienger JL. Pathologie du système endocrinien. In: Flament J, Storck D, editors. Oeil et pathologie Générale. Paris: Societé Française d'Ophtalmologie et Masson. 1997;9:339-341.

12. Edén S, Sundbeck G, Lindstedt G, et al. Screening for thyroid disease in the elderly. Serum concentrations of thyrotropin and 3,5,3'triiodothyronine in a representative population of 79-year-old women and men. Compr Gerontol A. 1988;2(1):40-45.

13. Schectman JM, Kallenberg GA, Shumacher RJ, Hirsch RP. Yield of hypothyroidism in symptomatic primary care patients. Arch Intern Med. 1989;149(4):861-864.

14. Bilous RW, Tunbridge WM. The epidemiology of hypothyroidism: an update. Baillieres Clin Endocrinol Metab. 1988;2(3):531-540.

15. Hertel E. Einiges uber den augendruck and glaukom. Klin Monatsbl Augenheilkd. 1920;64:390-392.

16. Pohjanpelto $P$. The thyroid gland and intraocular pressure. Tonographic study of 187 patients with thyroid disease. Acta Ophthalmol (Copenh). 1968;97(Suppl):1-70.

17. McLenachan J, Davies DM. Glaucoma and the thyroid. Br J Ophthalmol. 1965;49(8):441-444.

18. Krupin T, Jacobs LS, Podos SM, Becker B. Thyroid function and the intraocular pressure response to topical corticosteroids. Am JOphthalmol. 1977;83(5):643-646.

19. Centanni M, Cesareo R, Verallo O, et at. Reversible increase of intraocular pressure in subclinical hypothyroid patients. Eur J Endocrinol. 1997;136(6):595-598.

20. Girkin CA, McGwin G Jr, McNeal SF, Lee PP, Owsley C. Hypothyroidism and the development of open-angle glaucoma in a male population. Ophthalmology. 2004;111(9):1649-1652.

21. Motsko SP, Jones JK. Is there an association between hypothyroidism and open-angle glaucoma in an elderly population? An epidemiologic study. Ophthalmology. 2008;115(9):1581-1584.

research papers are published that cover all aspects of optics, refraction and its application to the theory and practice of optometry. The manuscript management system is completely online and includes a very quick and fair peer-review system, which is all easy to use. Visit http://www.dovepress. com/testimonials.php to read real quotes from published authors. 